\title{
The Use of Makassarese Language Based on Politeness Strategies: Review of the Universality of Yassi Theoretical Framework
}

\author{
Nurjannah Syarifuddin ${ }^{1}$ and Nona Siti Halimah ${ }^{2}$ \\ 1,2 Department of English Language Studies, Universitas Hasanuddin, Makassar, Indonesia \\ *ananurjannah21@gmail.com
}

\begin{abstract}
The study is aimed to revisiting the politeness framework of Yassi's. The study discusses the factor that influenced someone in used politeness strategies of heritage language in South Sulawesi especially Makassarese language. The methodology of this research is used qualitative method. The data were observed randomly from native speakers of Makassarese in did communication. On Yassi's theoretical framework found there are six politeness strategies. The strategies are deference in non-kinship, deference in kinship intimacy in non-kinship, intimacy in kinship, hierarchy in non-kinship and hierarchy in kinship. Yassi's exposed that the ages is one of the important part in politeness. A positive politeness strategy is used when communicate with friends, usually used casual and direct speech. When communicate with the older used negative politeness. In this study the writer found there are eight strategies that influenced someone in used politeness strategy to complete Yassi's theory. The new strategy is educated in non-kinship and educated in kinship. This study found someone will respect if did communicate with the educated people even though they are younger or older also kinship or in kinship.
\end{abstract}

Key words: Negative politeness, politeness strategy, positive politeness.

\section{Introduction}

Talking about communication and culture, Indonesia is rich in culture and ethnic groups in which each ethnic group has its own vernacular language to communicate. Every vernacular language has its own rule to arrange a proper conversation politely. One region in Indonesia, which has uniqueness in language, is South Sulawesi. In South Sulawesi, the people used some languages those are Makassarese, Buginese, and Torajanese [1].

Politeness is one of the strategies used to communicate which is one of the part of pragmatic. Pragmatic according to Leech is the study how the uttarnces has meaning in situation [2], because different situation would affect somone to understand what the speaker said. This is the important for human to learned politeness for each district, as we known politeness strategy is different in every region. Different languages would have different rules in using politeness strategies. This article discussed the politeness strategy used in Makassarese language. This study was revisiting the Yassi's politeness framework (1996) [3], [4]. In this era the politeness framework of Yassi is still effective or needs to be reformed. The variable in Yassi's politeness framework is the age, because the age is the dominant variable that can affect someone in used politeness strategies or not. The data were taken from some 
authors that research about politeness. The data related to Yassi's (1996). This dialogue would analyzed by using Yassi's theory.

\section{Theoretical Reviews}

Every language must have its own politeness strategy. Politeness is the language that is used in a polite way to communicate with each other [5], [6]. Usually politeness is used when we are talking with someone older than us. Every language must have its own rule in using politeness strategies. It is interesting to research because we may learn about the language that is used in every country and every region, to avoid misunderstanding between the users of languages.

There ware some theories about politeness. The theories are from Leech (1983), Brown and Levinson (1987), Holmes (1995), Scollon and Scollon (1995), and the last is Yassi (1996, 2011). All the theories have their own characteristics that are different from each other. Lakoff (1973) found the principle of politeness [7]. Leech (1983) found there are six maxims [8]. Brown Levinson (1987) found positive and negative politeness in his theory. Holmes (1995) distinguished the positive and negative politeness (Brown Levinson theories) based on the gender of the user of language [9]. Scollon and Scollond found the variable that determines the low value of variable $\mathrm{P}$ and the high value of the variable D (-P, +D) [10]. The last is Yassi theory $(1996,2011)$, adapting B\&L's and S\&S's framework, developed a politeness theoretical framework by introducing a new politeness system which has been empirically proven to be more effective and compatible for heritage languages in Indonesia, see for instance Yassi 2011, 2012, 2016a, 2016b, 2016c, and 2019 [11], [12], [13], [14]. Yassi found politeness strategies into six types of social relation patterns governing politeness strategies employed by the participants in an interaction.

\section{Symetrical Relations}

1. Deference in non kinship $(-\mathrm{P},+\mathrm{D},-\mathrm{K})$, example; interaction among strangers, they are know one another.

2. Deference in kinship $(-\mathrm{P},+\mathrm{D},+\mathrm{K})$, example; interaction among distant relatives

3. Intimacy in non-kinship (-P,-D,-K), example; interaction among friends, colleagues, and close friends

4. Intimacy in kinship $(-\mathrm{P},-\mathrm{D},+\mathrm{K})$, example; interaction among family members

\section{Asymetrical Relations}

1. Hierarchy in non-kinship $(+\mathrm{P},+\mathrm{D},-\mathrm{K})$, example; interaction between superordinate and subordinate, seniors and juniors.

2. Hierarchy in kinship $(+\mathrm{P},-\mathrm{D},+\mathrm{K})$, example; interaction between parents and children, uncle/aunt and nephew/niece, grandparents and grandchildren, and the likes.

According to Yassi's theory, there are some politeness strategies that are used in Makassar. Yassi found six politeness strategies that had been adopted from Brown Levinson \& Scollon Scollon. The six strategies are deference in non-kinship, deference in kinship, intimacy in non-kinship, intimacy in kinship, hierarchy in non-kinship and hierarchy in kinship.

In this modern era education is one of the priorities that someone needs. Someone who has more intelligence will be respected in society. The society will be respected if someone has a higher educational level than her. In this case, the educational side is higher than the age.

In Makassar, someone will talked more polite if they talk with the educational person than herself. Even though she is older than the educational person, she will use polite strategy. So according to that hypothesis, the writer found other politeness strategies. The writer has found the new politeness strategies. The two new politeness strategies will complete Yassi's theory.

\section{Yassi's Theory of Politeness Strategies}

1. Deference in non kinship $(-\mathrm{P},+\mathrm{D},-\mathrm{K})$

2. Deference in kinship $(-P,+D,+K)$

3. Intimacy in non-kinship $(-\mathrm{P},-\mathrm{D},-\mathrm{K})$

4. Intimacy in kinship $(-\mathrm{P},-\mathrm{D},+\mathrm{K})$

5. Hierarchy in non-kinship $(+\mathrm{P},+\mathrm{D},-\mathrm{K})$

6. Hierarchy in kinship $(+\mathrm{P},-\mathrm{D},+\mathrm{K})$

7. Educated in non-kinship $(+\mathrm{P},+\mathrm{D},+\mathrm{K})$

8. Educated in kinship $(+\mathrm{P},+\mathrm{D},+\mathrm{K})$ 


\section{Methodology}

Methodology of this research is used as a qualitative method. According to Creswell (1994:2), he said that "qualitative is a process of understanding social or human problems in complex building, holistic picture, formed in verbal languages" [15]. In this research, language is an object of the research. The researcher observed the native speakers of Makassarese in used Makassarese language. The researcher observed randomly and used note taking to collect the data.

\section{Findings and Discussions}

This part the researcher discussed about the finding of this research and discussed the data.

\section{Finding}

After doing research and analyzing the data, the researcher found the new strategies that were used in Makassar. Beside six strategies that found by Yassi, the researcher found there are two other strategies that the native speakers of Makassarese used communicate. The strategies based on educational background. The two strategies are educated in non-kinship and educated in kinship. The two strategies included the communication around the member of family, friends, superior or junior and also the younger or the older person.

\section{Discussion}

Makassarese Language

\section{Deference in Non-kinship $(-P+D-K)$}

The two data in below, showed the politeness strategy non-kinship. The dialogue (a) between two persons that does not know each other (A: The buyer B: The seller). The second dialogue (b) between two people that meet for the first time (A: Speaker and B: Hearer)

1.

A : Siapa katte anne ballina sandalaka?

- How you this price slipper

-(How much the price of this slipper?)

B : Punna antu tallumpulo lima sabbu hargana.

-If that thirty thousand price

-(That is price is thirty five thousand)

2.

A : Tabe, eroka akkuta'nang anne, ki issengi ballana dg bau

-Excuse me will+me ask this, you know house dg. Bau

-(Excuse me, I want to ask, do you now Dg. Bau's House?)

B :Dg bau? Njoreng antu ballana ri rampi'na masijika.

-Dg bau? There that house in beside mosque

-(Dg. Bau? Her house beside the mosque)

According to the dialogue above, the strategy that the speaker used is a negative politeness strategy. Where the speaker used that for the first time to meet with the hearer usually used politeness to show if the speaker is a kind person. The speaker B used a casual strategy when responding to speaker A.

\section{Deference in Kinship $(-P+D+K)$}

This dialogue is between two people in-kinship but they are the same age.

1.

A : Tena nu ciniki ammakku?

- No you see mother me

-(Don't you see my Mom?)

B : Tena, angngapaika? Tenai ri balla'nu?

-No why

-(No, what happened?)

A : Tenaja, iyo tenai riballa?

- Nothing yes no at home

-(No matter, because she is not at home) 
From the dialogue above, we can see the strategy that the speaker used is the same strategy. Both used casual strategy when communicating. The speaker A and B used the suffix -nu that means you but in an impolite word. Beside that the speaker A responded the speaker B used the words Iyo that means yes, but in impolite words. The two speakers used the casual strategy because they are so close with each other.

Intimacy in Non-kinship (-P-D-K)

These dialogues are between two people of non-kinship, where speaker B is older than speaker A.

A : Tette siapa ni ero a'lampa ri kampusuka?

- Time how you will go to campus

-(What time you will go to campus?)

$\mathrm{B}$ : Tettee salapang pi deh, ka erokka angnganre rong. Kau iya?

- Time nine I will eat first, you?

-(At nine pm cause I will eat first. What about you?)

A : Iyye, tena tompa, siagang peki a'lampa deh?

- Yes no also with me go

-(Not yet, we will go together)

2.

A : Erokki seng a'lampa kemae antu?

- Will+you go where that

-(What time you will go to campus?)

B : Tenaja jinne, ero'ja mange a'jampa-jampa

- Nothing Jinne will I go walking

-(Nothing Jinne, I just wanna go for refreshing)

A : Kemae bura'nennu??

- Where husband+you

-(Where is your husband?)

B : A'lampai katte ammekang siagang aga-aganna

- Go you fishing with friends

-(He go for fishing with his friends)

From the dialogue above, the speaker A that is older than speaker B used a casual strategy to communicate. We could see from the words that the speaker B used such as, Kau and suffix -nu that means you but on the casual side. While the speaker A used a negative politeness strategy to communicate with the speaker $\mathrm{B}$.

\section{Intimacy in Non-kinship $(-P-D+K)$}

This dialogue is between two people in-kinship, in which the speaker A is the little sister and the speaker B is the older sister.

A : Kak, sibukki?

- Sister busy+you

-(Sister, are you busy?)

B : Tenaja ndi, angngapai?

- Nothing sister why

- (No, what happen?)

A : Nia tugasku, na tena ku issengi, gappaka kulleki?

- There is task+me no me know maybe can+you

-(I have an assignment, and I do not know it, can you help me)

B : Tugas apaka?

- Task what

-(What task is it?)

A : Bahasa inggris kak,tena ku issengi battuanna anne

- Language English sister no me know meaning this

-(English, Sister. I do not know what does it means)

B : Sinampe pi pale ku bantuko, erokka rong a' je'ne

- Later I help+you will+me also water

-(Later I will help you, I will take bath first) 
The dialogue above also showed a politeness strategy. The speaker A was a little sister that used a negative politeness strategy to communicate with her older sister. We could see from the words that were used, such as, the use of the suffix -ki. In south Sulawesi the use of suffix -ki means you on the polite side and suffix -ko means you also but on the impolite side.

\section{Hierarchy in Non-kinship $(+P+D-K)$}

This dialogue is between two people of non kinship but they are in the same place or region. The speaker $\mathrm{A}$ is the older and the speaker $\mathrm{B}$ is the young.

1.

A : Antekamma mi kulliahnu, le'bammi?

- How study+you finish

-(How is your study? Have done)?

B : Tenapa katte

- Not yet you

- (Not yet, sir)

2.

A : Ngapana tena nu mange a'balanja ri pasaraka?

- Why no you go buy in to Market

-(Why you did not go to market?)

B : Le'ba'ma katte a'balanja, beru-beru?

- Have me you buy new

-(I have already buy it)

A : Tena nu ciniki berkasku ri mejayya?

- No you see file+me on table

-(Do not you see my file on the table?)

$\mathrm{B}$ : ena katte pak

- No you sir

-(No sir)

The dialogue above showed the politeness strategy that speaker B used. Because speaker A is an older person, speaker B used a negative politeness strategy when communicating, while speaker A used a casual strategy.

Hierarchy in Kinship $(+P-D+K)$

This dialogue between two people in-kinship, speaker A is the husband and Speaker B is the wife

1.

A : Mantang, nia tau akkio, assulukko be

- Mantang there is people calling out+you

-(Mantang, someone in outside, let you see there)

B : Tayangmi daeng, ku boliki rong sassangku

- Wait Daeng I save clothes+me

- (Please wait daeng, I save my laundry first)

2.

A : Tena ka antu kulle ni ca'ma-ca'ma?

- No that can eat

-(Is there any snack or cake?)

B : Kau antu sanging ero'nu a'ca'ma?

- You that always will+you eating

-(Why you always want to eat?)

A : Ngapami deeh, ka cipuru ki?

- Why hungry me

-(I am hungry)

From the dialogue above there are two kinds of strategy that the speaker B used. First is the use of a positive politeness strategy when communicating with her husband. The second is casual strategy. The two dialogues are different in use of strategy, even though the participants are the same. Because in south Sulawesi especially in Makassar the wife in some situations will use a positive politeness strategy to her husband and the use of negative politeness strategy in a bad situation. Bad situation, like when the wife is angry or in a bad mood, it will influence the use of casual strategy by her husband. 


\section{Educated in non-kinship $(+P,+D,+K)$}

This dialogue is between two people that know each other but the first person has a higher educational background than the second person.

1. $B$ is higher educated than $A$ and $B$ is younger than $A$

\section{A : Assikolaki'?}

- Study+you

-(Are you studying?)

$\mathrm{B}$ : Iyye, tenapa katte

- Yes, not yet you

- (Not yet)

A : Ikka kulleja mange antueng punna le'baki kuliata? Nia tugasna anakku ero'ni pring

- Ikka can I goes to there if done+you study+you? There is assignment child+me will print

-(May I go to you if your study has been done?)

B : Nia kuliaku kamma-kamma anne anggenna tangalloa, sinampepi ku prin?

- There is study+my now this until noon, later I print

-(I am studying now till the noon, later I will print it)

A : Chatma pale punna le'bamiki pringi dii?

- Chat+me if have done+you print

- (Please, chat me if you have to print it)

The dialogue above is between two persons that know each other but in kinship. The strategies that are used are the politeness strategy. A is older than B, but A used negative politeness strategy when talking with B. A used negative politeness strategy because $B$ has a higher educational background than A. On the other hand B also used negative politeness strategy. B used a negative politeness strategy because $B$ is older than $A$. So she needed to speak politely to A. Even though B has a higher educational background than A, she knew if we talked to the older person she needed to use a negative politeness strategy.

2. A is higher educated than $B$ and $A$ is older than $B$. This dialogue is between two friends that work in the same place. $A$ is older than $B$ and $A$ also has higher education than $B$.

A : Battu kemaeki antu Pak?

- Arrived where+you that Sir?

-(Where have you been Sir?)

B : Battua angngajara' anne Bu?

- Arrived teached this Mis

-(I had been teaching Mis)

A : Tette siapa sinampe ningngajara Pak?

- Hour how later you+teached Sir

- (Please, chat me if you have to print it)

B : Tette se'repi Bu. Nia' rapa' sinampe Bu?

- Hour one Mis. There is a meeting later Mis?

- (At one PM Mis. Is there any meeting?)

A : Iyye Pak nia' tette sampulo

- Yes Sir there is hour ten

-(Yes Sir, at ten AM)

All the speakers in the dialogue above used a politeness strategy. Even though A is older than B, she still used negative politeness to $\mathrm{B}$. $\mathrm{B}$ also used negative politeness to $\mathrm{A}$, cause he is younger than $\mathrm{A}$.

3. This dialogue between two friends in the same class. Speaker A and B have the same level of educational background.

A : Erokki amminawang kelas TOEFL?

- Will+you join class TOEFL?

-(Will you join in TOEFL class?)

B : Siagangki nai??

- With whom?

-(With whom is the class)

A : Siagangjeki agang-agang kelasta?

- With friends class+our

- (With our classmates)

B : Oh, ping siapami anjo pertemuanga?

- Oh, how that meeting?

- (Oh, how many meeting have done?)

A : Tenaja, nakke nampai tompa sikali amminawang 
- Nothing, I new also one join

-(Nothing, I just one time joined that class)

$\mathrm{B}$ : Iyye pale, ero'ja amminawang?

- Yes, will+I join?

- (Yes, I will join)

Educated in kinship $(+P,+D,+K)$

In this part there are three dialogues. This is a dialogue between two people in kinship, but the one has a higher education than the other one

1. The dialogue between two cousins. Speaker A is younger than speaker B and speaker A is higher educated than B.

B : Battuki seng rikampuska?

- Arrive+you at+campus?

-(Have you been to campus?)

A : Iyye, nia urusangku katte

- Yes, there is affair you

- (Yes, I have some affairs)

$\mathrm{B}$ : Maeki rong angnganre pale?

- Let+you eat

-(Let you eat first)

A : Sinampe pi katte, bassoro' inja

- Later you, full I

-(Later, I am still full)

The dialogue above used a politeness strategy. When someone talks with a person younger than herself, she will use casual form. But the dialogue above the speaker B used negative politeness. The speaker A also used negative politeness. From the dialogue above, it does not matter if you are younger than someone. If you are an educated person, you will respected by other people.

2. This dialogue between grandchild (A) and the cousin of his grandmother (B). The grandchild had finished his degree.

A : Antekamma kabaratta amma?

- How news grandmother

- (How are you grandma?)

B : Bajik-bajikji anak, sallona seng nampa battu?

- Fine child long new come?

-(I am good, it had been a long time you come)

A : Iyye amma, nampai selesai kuliahku?

- Yes grandmother, had been study+my

-(Yes grandma my study has finished)

B : Anjama meki kah nak?

- Work you child

- (Do you work now?)

A : Nampaia ero' wawancara anne amma?

- New will interview this grand mother

- (Later I will interview grandma)

B : Nakku' ku rikatte anak

- Miss I to+you child

-(I miss you)

A : Iyye amma, ka nampai anne nia wattuku?

- Yes grandmother new this there is time+my

- (Yes grandma, I just have a time)

The dialogue above used a politeness strategy. Both of the speakers used negative politeness. Even though the speaker B is older than speaker A, she still used negative politeness. It is because the speaker A is an educated person so someone will respect him including his family.

\section{Conclusion}

Politeness is one of the most important part that someone needs to know before communicating. Especially in South Celebes, there are some rules that someone needs to know when communicating. According to the data that has been explained, there are some factors that influence the politeness strategy in doing communication. Age is the 
first factor that influences someone to use a negative politeness strategy. Whether they know each other or do not know each other, they are superiors or subordinates, and they are senior or junior if they are older than the speaker so the speaker will use the politeness strategy. The second factor is the status in a family. Usually the wife will use a politeness strategy when talking with their husband. The other hand, a mother will use a politeness strategy when communicating with her children to educate the children to always be kind and have a good attitude and behavior. The last factor is educational background. Someone that has a high level of educational background will be respected by all people. It does not matter if they are your family or not and someone older than you or younger than you or the same age as you, they will respect you. They will use negative politeness when talking with you.

\section{References}

[1] A. K. Manyambeang, A. A. Syarif, A. R. Hamid, D. Basang, and A. Arief, Morfologi dan Sintaksis Bahasa Makassar. Pusat Pembinaan dan Pengembangan Bahasa Departemen Pendidikan dan Kebudayaan, Jakarta, 1979

[2] G. Yule, Pragmatics. New York: Oxford University Press, 1996

[3] A.H. Yassi, "Negating and Affirming a Proposition in Makassarese: A Cross-Cultural Communication Study," Unpublished Master Research Paper, Department of Linguistics, The University of Sydney, NSW, Australia, 1996.

[4] A.H. Yassi, "Teori Sistem Kesantunan Budaya Bahasa Makassar," Prosiding Kongres Bahasa Daerah Sulawesi Selatan, Makassar, 2012.

[5] P. Brown and S. C. Levinson, "Universals in Language Use: Politeness Phenomena" In E. Goody, Questions and Politeness: Strategies in Social Interaction. Cambridge: Cambridge University Press, 1978, pp. 56-311.

[6] P. Brown and S. C. Levinson, Politeness: Some Universals in Language Usage. Cambridge: Cambridge University Press, 1987.

[7] R. Lakoff, “Language and woman's place, ” Language in society, vol 2, issue 1, pp 45-80, Apr 1973

[8] G. Leech, Principles of Pragmatics. London: Longman, 1983

[9] J. Holmes, Women Men and Politeness. London: Longman, 1995.

[10] R. Scollon and S.B.K. Scollon, Intercultural Communication: A Discourse Approach. Oxford, Cambridge: Blackwell, 1995

[11] A.H. Yassi, "Model Kerangka Teori Kesantunan yang Efektif Mengkaji POla Kesantunan Bahasa-Bahasa di Indonesia: Mempertanyakan Keuniversalitasan Kerangka Teori Kesantunan Brown \& Levinson," Prosiding Seminar Antar Bangsa (ASBAM), Makassar, 2016.

[12] A.H. Yassi, "Ancangan Model Kerangka Teori Kesantunan yang Efektif Mengkaji Budaya Bahasa-Bahasa Heritage di Asia: Review terhadap Keuniversalitasan Kerangka Teori Kesantunan Brown \& Levinson," Prosiding Kongres Internasional Linguistik (KIMLI), Bali, 2016

[13] A.H. Yassi, "Pemetaan Pola Sistem Kesantunan Budaya Bahasa-Bahasa Sulawesi Selatan dan Barat (Sulselbar): Harmonisasi Kehidupan Sosial Bertetangga," Prosiding Seminar Nasional Bulan Bahasa Fakultas Ilmu Budaya Universitas Hasanuddin, Makassar, 2016.

[14] A.H. Yassi, "Ancangan Model Kerangka Teori Kesantunan Yang Efektif Mengkaji Budaya Bahasa-bahasa Heritage di Asia," Medan Bahasa, vol 1, issue 1, pp 11-21, Feb 2019.

[15] J. W. Creswell, Qualitative inquiry and research design: Choosing among five approaches. Sage Publications, 2016. 